\title{
The Implementation of ACM/AIS IS 2010 in the Undergraduate Programs of Information Systems in Indonesia
}

\author{
Arif Wibisono \\ Department of Information Systems \\ Institut Teknologi Sepuluh Nopember (ITS) \\ Jalan Raya ITS Sukolilo, Surabaya, Indonesia
}

\begin{abstract}
Information systems discipline has emerged as a multidisciplinary field. As time progresses, we witness a wide interpretation of IS curriculum within undergraduate programs worldwide. This paper seeks to measure the concordance of IS curriculum in the undergraduate programs in Indonesia with world-widely-adhered ACM/AIS IS Curricula 2010. To this point, we attempt to extract local direction of IS undergraduate programs in Indonesia. Also, we investigate commonly local subjects that are available but may not necessarily close with the topic of IT and organization. We gather curriculums and syllabuses from 55 IS undergraduate programs in Indonesia and map them with ACM/AIS IS 2010. As a comparison, we benchmark our result with our previous study in 2013. As a result, we have identified that most IS undergraduate programs in Indonesia do not fully comply with what ACM/AIS IS 2010 provides. Both Enterprise Architecture and IS Strategy are still under taught topics. Application Development is still playing important role in IS undergraduate programs despite their revocation in ACM/AIS IS Curricula 2010. These results are consistent with what we have obtained in 2013
\end{abstract}

Keywords-Information Systems Curricula, ACM/AIS IS 2010, undergraduate program

\section{INTRODUCTION}

Information Systems (IS) is a multidisciplinary discipline that incorporates various disciplines besides its computing root such as psychology, sociology, business, and management science [1]. As time goes by, Information Systems programs emerges not only in Computing or Engineering programs but also in Business programs. Hence, the curriculum structure among Information Systems programs are varying from one program to another program even in their very core courses [2] [3]. While Information Systems has wide interpretation, it has obvious nature which is the implementation of information systems and information technology in corporate organization[4].

For this reason, Association for Information Systems (AIS) and Associated Computing Machinery (ACM) work together in developing curriculum guidelines to accommodate these diversities [5]. Here, AIS is a notable association for information systems disciplines worldwide while ACM is a prominent association for computing disciplines. The guidelines themselves are necessary to distinguished IS with other computing discipline such as software engineering, computer engineering, computer science, and information technology [5][6]. The recent curriculum guideline for Information System is ACM/AIS IS 2010 [5].

The making of IS Curriculum Guidelines has started in the beginning of 1970 's by a variety of academic communities. For instance ACM has introduced the first curriculum guidelines for Information Systems in 1970 [7]. Nowadays, there are several active communities that have responsible of the curriculum guideline making such as Associated Computing Machinery (ACM), Association for Information Systems (AIS), and Association of Information Technology Professional (AITP). There have been several curriculum guidelines worldwide namely ACM 1983 [8], DPMA in 1990 [9], IS 97[10], IS 2002 [11], and IS 2010 [5]. Among them IS 97[10] and IS 2002 [11] are two curriculum guidelines that established jointly by three aforementioned organizations: ACM, AIS, and AITP.

ACM/AIS IS 2010 constructs its curriculum according to what so called as "high level capabilities". Here, high level capabilities are a set of knowledge and skills that an information system professional should attain after graduation. There are seven high level capabilities: 1) improving organizational processes, 2) Exploiting opportunities created by technology innovations, 3) Understanding and addressing information requirements, 4) Designing and managing enterprise architecture, 5) Identifying and evaluating solution and sourcing alternatives, 6) Securing data and infrastructure, and 7) Understanding, managing and controlling IT risks. In order to master those high level capabilities, ACM/AIS IS 2010 breaks down the high level capabilities into three groups of knowledge and skills: a) IS specific knowledge and skills (IS Specific), b) Foundational knowledge and skills (IS Foundation), and c) Domain fundamentals.

IS specific is a set of knowledge and skills that are distinctive to IS discipline and is the core of IS discipline. 
There are seven core courses in the IS Specific that are 1) Foundation of Information Systems 2) Data and Information Management 3) Enterprise Architecture 4) IS Project Management 5) IT Infrastructure 6) System Analysis and Design 7) IS Strategy, Management, and Acquisition. IS Foundation is any knowledge and skill that is not specific to IS and is important to deal with organizational issues such as negotiation skills, leadership, analytical thinking, and creativity. IS foundation is pivotal not only for IS professional but also for any professional dealing with organizational environments. Domain fundamental is the third category of knowledge and skill. Domain fundamental encompasses the business domain where IS will be applied. Normally, general business is the domain, but many other business specialties may appear in the curriculum such as accounting, finance, and healthcare.

TABLE I. COMPARISON OF THE IS SPECIFIC AMONG IS'97, IS 2002, AND IS 2010 GUIDELINES [12]

\begin{tabular}{|c|c|c|}
\hline IS 1997 & IS 2002 & IS 2010 \\
\hline $\begin{array}{c}\text { S.97.P0 Knowledge } \\
\text { Work Software } \\
\text { Tool } \\
\end{array}$ & \multirow{2}{*}{$\begin{array}{c}\text { IS. 2002.P0 Personal } \\
\text { Productivity with IS } \\
\text { Technology }\end{array}$} & \multirow[b]{2}{*}{ Abolished } \\
\hline $\begin{array}{c}\text { S'97 Personal } \\
\text { Productivity with IS } \\
\text { Technology }\end{array}$ & & \\
\hline $\begin{array}{l}\text { IS } \mathbf{9 7 . 1} \\
\text { Fundamentals of } \\
\text { Information } \\
\text { Systems }\end{array}$ & $\begin{array}{c}\text { IS. 2002.1 } \\
\text { Fundamentals of } \\
\text { Information Systems }\end{array}$ & $\begin{array}{l}\text { IS 2010.1 } \\
\text { Foundation of } \\
\text { Information } \\
\text { Systems }\end{array}$ \\
\hline Not Existed & $\begin{array}{c}\text { IS 2002.2 } \\
\text { Electronic Business, } \\
\text { Strategy, Architecture } \\
\text { and Design }\end{array}$ & $\begin{array}{c}\text { IS 2010.7 } \\
\text { IS Strategy, } \\
\text { Management } \\
\text { and Acquisition }\end{array}$ \\
\hline $\begin{array}{l}\text { IS. 97.3 Information } \\
\text { Systems Theory } \\
\text { and Practice }\end{array}$ & $\begin{array}{c}\text { IS. 2002.3 Information } \\
\text { Systems } \\
\text { Theory and Practice } \\
\end{array}$ & Abolished \\
\hline $\begin{array}{l}\text { IS } \mathbf{9 7 . 4} \text { Information } \\
\text { Technology } \\
\text { Hardware and System } \\
\text { Software }\end{array}$ & $\begin{array}{c}\text { IS 2002.4 Information } \\
\text { Technology } \\
\text { Hardware and System } \\
\text { Software }\end{array}$ & Abolished \\
\hline $\begin{array}{c}\text { IS } \mathbf{9} 97.5 \\
\text { Programming, Data, } \\
\text { File and Object } \\
\text { Structures }\end{array}$ & $\begin{array}{c}\text { IS 2002.5 } \\
\text { Programming, Data, } \\
\text { File, and Object } \\
\text { Structures }\end{array}$ & Abolished \\
\hline \multirow[b]{2}{*}{$\begin{array}{l}\text { IS } 997.6 \text { Network and } \\
\text { Telecommunication }\end{array}$} & \multirow[b]{2}{*}{$\begin{array}{l}\text { IS 2002.6 Network and } \\
\text { Telecommunication }\end{array}$} & $\begin{array}{c}\text { IS 2010.4 } \\
\text { IT Infrastructure }\end{array}$ \\
\hline & & $\begin{array}{c}\text { IS 2010.3 } \\
\text { Enterprise } \\
\text { Architecture }\end{array}$ \\
\hline $\begin{array}{l}\text { IS '97.7 Analysis and } \\
\text { Logical Design }\end{array}$ & $\begin{array}{l}\text { IS 2002.7 Analysis and } \\
\text { Logical Design }\end{array}$ & $\begin{array}{c}\text { IS 2010.6 } \\
\text { System Analysis } \\
\text { and } \\
\text { Design }\end{array}$ \\
\hline $\begin{array}{c}\text { IS } 997.8 \text { Physical } \\
\text { Design and } \\
\text { Implementation with } \\
\text { DBMS }\end{array}$ & $\begin{array}{l}\text { IS 2002.8 Physical } \\
\text { Design and } \\
\text { Implementation with } \\
\text { DBMS }\end{array}$ & $\begin{array}{l}\text { IS 2010.2 Data } \\
\text { Management }\end{array}$ \\
\hline $\begin{array}{c}\text { IS 97.9 Physical } \\
\text { Design and } \\
\text { Implementation with a } \\
\text { programming } \\
\text { environment }\end{array}$ & $\begin{array}{l}\text { IS 2002.9 Physical } \\
\text { Design and } \\
\text { Implementation in } \\
\text { Emerging } \\
\text { Environment }\end{array}$ & Abolished \\
\hline
\end{tabular}

Table I, Cont.

\begin{tabular}{|c|c|c|}
\hline $\begin{array}{c}\text { IS 97.10 Project } \\
\text { Management and } \\
\text { Practice }\end{array}$ & $\begin{array}{c}\text { IS'97.10 Project } \\
\text { Management and } \\
\text { Practice }\end{array}$ & $\begin{array}{c}\text { IS 2010.5 IS } \\
\text { Project } \\
\text { Management }\end{array}$ \\
\hline
\end{tabular}

Distinct from the previous guideline efforts, the focus of ACM/AIS 2010 is shifting towards Business rather than Computing [5]. One of major changes in the guideline is that the ACM/AIS IS 2010 has removed application development course from its core courses. [5]. This step is quite surprising since application development has been IS core course since its inception as a new discipline. To accommodate several non-business IS programs, ACM/AIS IS 2010 includes application development as an elective[5]. In the other hand, ACM/AIS IS 2010 includes new core named Enterprise Architecture which study materials are more strategic in planning and designing organizational solutions [5].

Even though ACM/AIS IS 2010 is the de jure standard of IS undergraduate programs, many IS undergraduate programs do not fully incorporate ACM/AIS IS 2010. Australia Computer Society (ACS) chooses to partially include two core courses in their local curriculum guideline: 1) Enterprise Architecture and 2) IS Strategy, Management, and Acquisition. Nevertheless the two core courses are attached in IS postgraduate programs [13]. Likewise, many IS undergraduate programs in Indonesia not totally cover the two topics [12]. Different from Australia based IS undergraduate programs which two topics revocation are top-down initiatives, the revocation initiatives are triggered independently by each university[12]. Also, the low inclusion of Enterprise Architecture topic is evident in the US [14]. To this point, most US bachelor programs put more emphasis on Data and Information Management[14]. Moreover, the lack addressment of the ACM/AIS IS 2010 in the job market demand is another reason for many bachelor degree programs to completely adhere ACM/AIS IS 2010 [15].

This paper aims at understanding the compliance level of Indonesian IS undergraduate programs towards ACM/AIS IS 2010. By understanding the IS programs compliance, we could measure whether ACM/AIS IS 2010 is suitable in the Indonesian setting. Furthermore, we intend to understand the focus of IS undergraduate programs in Indonesia. Here, we intend to extract the facts whether the IS programs are closer to computing discipline or closer to business discipline. As a comparison, we benchmark the result with our previous effort done in 2013 [12]. In our previous study, we have found that Enterprise Architecture and IS Strategy are two subjects that were removed from many IS undergraduate Programs. In the other hand, programming and system development received a large portion of the curriculum. Hence, we could say that in general, IS undergraduate programs in Indonesia were closer to computing discipline rather than to business discipline.

The remainder of the paper is divided into four sections. In 
the section one, we outline the background of our research and reason the importance. Also we provide literature studies of our research. In this section, we briefly explain the history of IS Curriculum development. In the section two, we outline our research method and how the method performed. In the section three, we show our results as well as provide analysis for discussion. Lastly, we conclude our work and highlight potential research area for research extension in the section five.

\section{METHOD}

There are several steps we use in this research: 1). Identifying information systems undergraduate programs in Indonesia, 2) Eliciting curriculums and syllabuses, 3). Extracting body of knowledge in IS 2010,4) Mapping curriculums and the body of knowledge, 5) Analyzing the mapping results, 6). Comparing previous research (2013), 7). Drawing conclusion.

TABLE II. LISTS OF IS SPECIFIC COURSES [12]

\begin{tabular}{|c|c|c|c|}
\hline No & Name & Keywords & Role \\
\hline 1 & $\begin{array}{l}\text { Foundation of } \\
\text { Information } \\
\text { Systems }\end{array}$ & $\begin{array}{c}\text { Introduction to IS, Computer and } \\
\text { Society }\end{array}$ & $\begin{array}{l}\text { Core } \\
\text { courses } \\
\text { (ACM/AIS } \\
\text { IS 2010) } \\
\end{array}$ \\
\hline 2 & $\begin{array}{c}\text { Data and } \\
\text { Information } \\
\text { Management }\end{array}$ & $\begin{array}{l}\text { Conceptual Data Modeling, Database } \\
\text { Management Systems, } \\
\text { Normalization, Database in the } \\
\text { Organizational Context, Data } \\
\text { Security, Data Warehousing }\end{array}$ & $\begin{array}{l}\text { Core } \\
\text { courses } \\
\text { (ACM/AIS } \\
\text { IS 2010) }\end{array}$ \\
\hline 3 & $\begin{array}{l}\text { Enterprise } \\
\text { Architecture }\end{array}$ & $\begin{array}{l}\text { IS/IT Investment, Risk Management, } \\
\text { Information Architecture Design, } \\
\text { Business Continuity, IS/IT Audit, } \\
\text { Enterprise Application Integration, } \\
\text { Service Oriented Architecture, } \\
\text { Distributed Computing, IT Control } \\
\text { and Service Management } \\
\text { Frameworks (e.g. ITIL) }\end{array}$ & $\begin{array}{l}\text { Core } \\
\text { courses } \\
\text { (ACM/AIS } \\
\text { IS 2010) }\end{array}$ \\
\hline 4 & $\begin{array}{c}\text { IS Project } \\
\text { Management }\end{array}$ & $\begin{array}{l}\text { Project Management Life Cycle, } \\
\text { Project Schedules, Project } \\
\text { Resources, Project Quality, Project } \\
\text { Risks. Project Scope, Project, } \\
\text { Procurement, Project Control and } \\
\text { Closure }\end{array}$ & $\begin{array}{l}\text { Core } \\
\text { courses } \\
\text { (ACM/AIS } \\
\text { IS 2010) }\end{array}$ \\
\hline 5 & $\begin{array}{c}\text { IT } \\
\text { Infrastructure }\end{array}$ & $\begin{array}{l}\text { Computer and Networks, Client- } \\
\text { Server, Service Virtualization, } \\
\text { Communication Protocol, IP } \\
\text { Networks, large-scale organizational } \\
\text { IT infrastructure, Cloud Computing, } \\
\text { Network Security, Digital Forensic }\end{array}$ & $\begin{array}{l}\text { Core } \\
\text { courses } \\
\text { (ACM/AIS } \\
\text { IS 2010) }\end{array}$ \\
\hline 6 & $\begin{array}{c}\text { System } \\
\text { Analysis and } \\
\text { Design }\end{array}$ & $\begin{array}{l}\text { Business Process Modeling, } \\
\text { Business Process Analysis, Data } \\
\text { Collection Methods, Requirement } \\
\text { Engineering, Analysis and Design of } \\
\text { IS, Software Development Life } \\
\text { Cycle, Change Management }\end{array}$ & $\begin{array}{l}\text { Core } \\
\text { courses } \\
\text { (ACM/AIS } \\
\text { IS 2010) }\end{array}$ \\
\hline 7 & $\begin{array}{l}\text { IS Strategy, } \\
\text { Management, } \\
\text { and } \\
\text { Acquisition }\end{array}$ & $\begin{array}{l}\text { Strategic Information Systems, } \\
\text { Information Economics, IS to } \\
\text { enhance Organizational performance, } \\
\text { IS Strategic Alignment, IS Planning, } \\
\text { IS/IT Governance }\end{array}$ & $\begin{array}{l}\text { Core } \\
\text { courses } \\
\text { (ACM/AIS } \\
\text { IS 2010) }\end{array}$ \\
\hline
\end{tabular}

In the first stage (Identifying IS undergraduate programs in Indonesia), we collect data of all Information Systems
Undergraduate Programs in Indonesia from http://forlap.dikti.go.id. This website is an official Directorate of Higher Education website and is available for public access. In the second stage (Eliciting curriculums and syllabuses), based on the website, we search syllabuses and curriculum from each department by manual Google crawling. There are 55 IS Undergraduate Programs that provide the curriculums and syllabuses through their official websites. This number is far below the active number of IS Undergraduate Programs (350 programs).

TABLE III. LISTS OF NON- IS SPECIFIC COURSES [12]

\begin{tabular}{|c|c|c|c|}
\hline No & Name & Keywords & Role \\
\hline 1 & $\begin{array}{l}\text { Application } \\
\text { Development }\end{array}$ & $\begin{array}{l}\text { Programming, Data Structure, } \\
\text { Internet and Web Development, } \\
\text { Application integration, } \\
\text { Prototyping, Database access, } \\
\text { Program design, Program } \\
\text { development lifecycle, }\end{array}$ & $\begin{array}{l}\text { Elective } \\
\text { courses } \\
\text { (ACM/AIS } \\
\text { IS 2010) }\end{array}$ \\
\hline 2 & $\begin{array}{c}\text { Business } \\
\text { Process } \\
\text { Management }\end{array}$ & $\begin{array}{l}\text { Business process definition and } \\
\text { classification, process } \\
\text { assessment, process } \\
\text { improvement, process analysis, } \\
\text { process redesign, process } \\
\text { monitoring }\end{array}$ & $\begin{array}{l}\text { Elective } \\
\text { courses } \\
(\text { ACM/AIS } \\
\text { IS 2010) }\end{array}$ \\
\hline 3 & $\begin{array}{l}\text { Enterprise } \\
\text { Systems }\end{array}$ & $\begin{array}{l}\text { Selection of enterprise systems } \\
\text { software, Organizational } \\
\text { change and change } \\
\text { management, Job redesign, } \\
\text { Governance of processes and } \\
\text { data Post-implementation } \\
\text { issues, Enterprise system } \\
\text { processes, Order processing. } \\
\text { Purchasing, Production } \\
\text { logistics, Accounting, Planning } \\
\text { and control, }\end{array}$ & $\begin{array}{l}\text { Elective } \\
\text { courses } \\
\text { (ACM/AIS } \\
\text { IS 2010) }\end{array}$ \\
\hline 4 & $\begin{array}{l}\text { Introduction to } \\
\text { Human- } \\
\text { Computer } \\
\text { Interaction }\end{array}$ & $\begin{array}{l}\text { Principles in HCI design, User- } \\
\text { Centered Design, Prototyping, } \\
\text { Contextual inquiry, Usability } \\
\text { engineering, Evaluation } \\
\text { Methods }\end{array}$ & 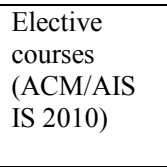 \\
\hline 5 & $\begin{array}{l}\text { IT Audit and } \\
\text { Controls }\end{array}$ & $\begin{array}{l}\text { Auditing ethics, guidelines, and } \\
\text { standards of the profession, } \\
\text { Undertaking an information } \\
\text { system audit, Controls over } \\
\text { information and processes, } \\
\text { Controls Assessment }\end{array}$ & $\begin{array}{l}\text { Elective } \\
\text { courses } \\
\text { (ACM/AIS } \\
\text { IS 2010) }\end{array}$ \\
\hline 6 & $\begin{array}{l}\text { IS Innovation } \\
\text { and New } \\
\text { Technologies }\end{array}$ & $\begin{array}{l}\text { Conversation about the } \\
\text { commoditization of IT, Process } \\
\text { of IS innovation, Knowledge } \\
\text { management, Web } 2.0 \text { tools }\end{array}$ & $\begin{array}{l}\text { Elective } \\
\text { courses } \\
\text { (ACM/AIS } \\
\text { IS 2010) }\end{array}$ \\
\hline 7 & $\begin{array}{l}\text { IT Security and } \\
\text { Risk } \\
\text { Management }\end{array}$ & $\begin{array}{l}\text { Introduction to information } \\
\text { security, security protection, } \\
\text { security detection, incident } \\
\text { management, security } \\
\text { engineering, digital forensic, } \\
\text { Policy and management issues }\end{array}$ & $\begin{array}{l}\text { Elective } \\
\text { courses } \\
\text { (ACM/AIS } \\
\text { IS 2010) }\end{array}$ \\
\hline 8 & Mathematics & $\begin{array}{l}\text { Basic Math, Discrete } \\
\text { Mathematics, Statistics, Linear } \\
\text { Algebra, Management Science, } \\
\text { Operation Research }\end{array}$ & $\begin{array}{l}\text { Math } \\
\text { Foundation }\end{array}$ \\
\hline 9 & Computing & $\begin{array}{l}\text { Operating Systems, Computer } \\
\text { Organization, Algorithm } \\
\text { Theory }\end{array}$ & $\begin{array}{l}\text { Computing } \\
\text { Foundation }\end{array}$ \\
\hline 10 & $\begin{array}{l}\text { General } \\
\text { Business }\end{array}$ & $\begin{array}{l}\text { Management, Organizational } \\
\text { Behavior }\end{array}$ & $\begin{array}{l}\text { Business } \\
\text { Foundation }\end{array}$ \\
\hline
\end{tabular}




\section{Tabel III, Cont.}

\begin{tabular}{|l|l|l|l|}
\hline 11 & Other & $\begin{array}{l}\text { Bahasa Indonesia, Interpersonal } \\
\text { Communication, Scientific } \\
\text { Research, Professional Ethics }\end{array}$ & $\begin{array}{l}\text { University } \\
\text { Mandatory } \\
\text { Course } \\
\text { (UMC) }\end{array}$ \\
\hline
\end{tabular}

We have found that many active IS undergraduate programs have no official websites. Surely, these website absences are pretty ironic since most IS Undergraduate Programs incorporate web programming or website related subjects in their curriculums. In the third stage (Extracting body of knowledge in IS 2010), we distill components of IS specific namely Foundation of IS, IS Strategy, IT Infrastructure, Enterprise Architecture, System Analysis and Design, Data Management, and IS Project Management (see Table II). In addition, we append new category: Non IS Specific which has several courses such as application development, business, mathematics, organization, mathematics, computing, enterprise systems, and other (see Table). In the fourth stage (Mapping curriculums and the body of knowledge), we carefully map existing curriculums and syllabuses from 55 IS undergraduate programs in Indonesia with what we have in Table II and Table. At this stage, we only use the mandatory courses (not elective courses). Afterwards, we analyzing the mapping result. Here, we use spider chart to map the differences between numerous IS undergraduate programs. In the six stage, we compare our obtained result with our previous similar effort in 2013. In the end, we draw conclusion. The conclusion reveals not only the compliance level but also the local direction of IS undergraduate programs in Indonesia.

\section{RESULTS AND DISCUSSION}

We obtained 55 syllabuses from various IS Undergraduate Programs in Indonesia. We categorize the programs into two groups: public universities and private universities. Public universities are mostly characterized with thick academic and non-pragmatic nature. In the other hand, private universities are more pragmatic in nature since they are not government supported. The inclusion of too many theoretical subjects may reduce their graduate employability, thus hindering more students for admission in the future.

In general, IS undergraduate programs in Indonesia do not fully follow what ACM/AIS IS 2010 have outlined. More specifically, despite the fact that Enterprise Architecture is a core topic in ACM/AIS IS 2010, it is existences are widely reduced in many syllabuses. This situation is true for all universities regardless their public or private status. The average credit of Enterprise Architecture is only 0.85 credits or around $1.27 \%$ of the ratio per university. One interesting result is that IS Strategy, Management \& Acquisition is still under taught topic in private universities, while in public universities, its existences are growing. This result indicates that the awareness of its importance is greatly improved in public universities (four credits in average and 3.91\% in ratio). In our previous study, we have found that IS Strategy,
Management \& Acquisition only counts $0.48 \%$ in ratio for public universities and $0.50 \%$ in private universities [12].

The most taught topic in all universities is "other". Other is not a single topic, but instead it is a topic of composites. Usually, "Other" consists of university-attached topics which are irrelevant to IS context but are important for university continuity. The exemplars of other are religion, civics, history, chemistry, physics, and sports. "Other" comprises of one fifth of mandatory courses

Moreover, many IS Undergraduate Programs still put strong emphasis in Application Development topic. For your information, Application Development is second to "other".in terms of prevalence. This is quite interesting since Application Development is not IS core after its removal in ACM/AIS IS 2010. The average credits for Application Development is 24.16 credits in average and is the largest among all topics including all IS cores. It is four times higher than that of Systems Analysis \& Design and IT Infrastructure and is three times higher than that of Data \& Information Management. Despite its prominent credit numbers, the credit number variance is also the highest among all topics (10.31 credits), especially in private universities (10.62 credits). It means that although many IS undergraduate programs perceive that Application Development is pivotal, but they do not come into a single agreement about the credit numbers.

Computing is also received significant credit numbers behind Application development. Computing encompasses any topics to pave a strong understanding of computational environment such as operating systems, computer architecture, and multimedia. There are $90,91 \%$ of IS undergraduate programs teach computing related topics (see Fig 2). By having these data, we could say that IS Undergraduate Program still maintain its computing root.

In another perspective, we can see that the local direction of IS undergraduate programs is more to strengthen system development. Fig 2 shows that system development related topics are applicable with percentage more than $89 \%$. The corresponding topics are as System Analysis \& Design (89.09\%), Data and Information Management (96.36\%), IS Project Management (96.36\%), and Application Development (98.18\%). Furthermore, the understanding of Information Systems Foundation is also perceived important to enrich system development. It is easily seen that this topic is discussed in all IS undergraduate programs (see Fig 2).

We do believe that this de-facto local direction is rather industrial driven than academic driven. Surely, this local direction may be problematic to distinct IS with similar computing disciplines in Indonesia such as Informatics Engineering (or Computer Science), Software Engineering, and Information Technology. Those disciplines also incorporate a substantial amount of credits to study the knowhow of system development. Until now, there is no agreement 
among discipline stakeholders to officially distinguish IS with other aforementioned disciplines. Especially, what type of industries that every discipline should address and at what roles.

\begin{tabular}{|c|c|c|c|c|c|c|c|c|c|c|c|c|}
\hline & \multicolumn{6}{|c|}{ Total Credits per university } & \multicolumn{6}{|c|}{$\begin{array}{c}\text { Ratio (credits/total credits of mandatory courses) } \\
\text { per university }\end{array}$} \\
\hline & \multicolumn{2}{|c|}{ Public Univ } & \multicolumn{2}{|c|}{ Private Univ } & \multicolumn{2}{|c|}{$\begin{array}{c}\text { All } \\
\text { Universities } \\
\end{array}$} & \multicolumn{2}{|c|}{ Public Univ } & \multicolumn{2}{|c|}{ Private Univ } & \multicolumn{2}{|c|}{ All Universities } \\
\hline & Avg & $\sigma$ & Avg & $\sigma$ & Avg & $\sigma$ & Avg & $\sigma$ & Avg & $\sigma$ & Avg & $\sigma$ \\
\hline IS Foundation & 9,50 & 4,96 & 12,26 & 6,25 & 11,65 & 6,06 & $7,99 \%$ & $4,87 \%$ & $8,49 \%$ & $3,58 \%$ & $8,38 \%$ & $3,86 \%$ \\
\hline Data \& Information Mgmt & 5,83 & 3,10 & 9,35 & 4,32 & 8,58 & 4,31 & $4,41 \%$ & $2,36 \%$ & $6,63 \%$ & $2,98 \%$ & $6,14 \%$ & $2,98 \%$ \\
\hline Enterprise Architecture & 0,75 & 1,36 & 0,88 & 1,66 & 0,85 & 1,59 & $0,56 \%$ & $1,01 \%$ & $0,64 \%$ & $1,25 \%$ & $0,63 \%$ & $1,20 \%$ \\
\hline IS Project Management & 3,58 & 1,93 & 3,65 & 1,59 & 3,64 & 1,65 & $2,93 \%$ & $1,64 \%$ & $2,60 \%$ & $1,07 \%$ & $2,67 \%$ & $1,21 \%$ \\
\hline IT Infrastructure & 6,50 & 3,42 & 3,88 & 3,74 & 4,45 & 3,80 & $5,13 \%$ & $2,37 \%$ & $2,77 \%$ & $2,63 \%$ & $3,29 \%$ & $2,74 \%$ \\
\hline System Analysis \& Design & 4,08 & 3,75 & 5,02 & 2,56 & 4,82 & 2,85 & $3,79 \%$ & $4,20 \%$ & $3,65 \%$ & $2,14 \%$ & $3,68 \%$ & $2,68 \%$ \\
\hline IS Strategy, Mgmt, \& Acq. & 4,00 & 5,78 & 1,30 & 2,22 & 1,89 & 3,45 & $3,63 \%$ & $5,35 \%$ & $0,89 \%$ & $1,52 \%$ & $1,49 \%$ & $2,99 \%$ \\
\hline Application Development & 18,83 & 7,20 & 25,72 & 10,61 & 24,22 & 10,31 & $14,85 \%$ & $4,56 \%$ & $18,09 \%$ & $6,51 \%$ & $17,39 \%$ & $6,25 \%$ \\
\hline Business Process Managment & 3,08 & 5,45 & 1,67 & 1,63 & 1,98 & 2,91 & $3,76 \%$ & $8,84 \%$ & $1,26 \%$ & $1,30 \%$ & $1,81 \%$ & $4,28 \%$ \\
\hline Enterprise Systems & 6,50 & 6,50 & 5,65 & 5,32 & 5,84 & 5,55 & $4,81 \%$ & $4,49 \%$ & $3,75 \%$ & $2,90 \%$ & $3,98 \%$ & $3,30 \%$ \\
\hline Human Computer Interaction & 1,83 & 1,40 & 2,19 & 1,35 & 2,11 & 1,36 & $1,40 \%$ & $1,09 \%$ & $1,60 \%$ & $1,10 \%$ & $1,55 \%$ & $1,09 \%$ \\
\hline IT Audit and Controls & 1,25 & 1,54 & 1,49 & 1,92 & 1,44 & 1,83 & $0,91 \%$ & $1,13 \%$ & $1,03 \%$ & $1,32 \%$ & $1,00 \%$ & $1,28 \%$ \\
\hline IS Innovation \& new Tech & 2,25 & 1,86 & 2,35 & 1,74 & 2,33 & 1,75 & $1,68 \%$ & $1,35 \%$ & $1,67 \%$ & $1,20 \%$ & $1,67 \%$ & $1,22 \%$ \\
\hline IT Security \& Risk Mgmt & 2,33 & 2,42 & 2,14 & 1,73 & 2,18 & 1,88 & $1,75 \%$ & $1,82 \%$ & $1,47 \%$ & $1,19 \%$ & $1,53 \%$ & $1,34 \%$ \\
\hline Mathematics & 9,17 & 4,43 & 9,79 & 4,81 & 9,65 & 4,70 & $6,91 \%$ & $3,24 \%$ & $6,86 \%$ & $3,02 \%$ & $6,87 \%$ & $3,04 \%$ \\
\hline Computing & 12,17 & 11,22 & 13,16 & 9,18 & 12,95 & 9,56 & $8,84 \%$ & $7,16 \%$ & $8,87 \%$ & $5,39 \%$ & $8,87 \%$ & $5,75 \%$ \\
\hline General Business & 8,67 & 13,63 & 10,58 & 11,02 & 10,16 & 11,53 & $6,75 \%$ & $10,44 \%$ & $7,55 \%$ & $9,21 \%$ & $7,38 \%$ & $9,40 \%$ \\
\hline Other & 28,91 & 11,49 & 31,16 & 9,13 & 30,70 & 9,58 & $19,89 \%$ & $9,96 \%$ & $22,18 \%$ & $5,19 \%$ & $21,68 \%$ & $6,49 \%$ \\
\hline
\end{tabular}




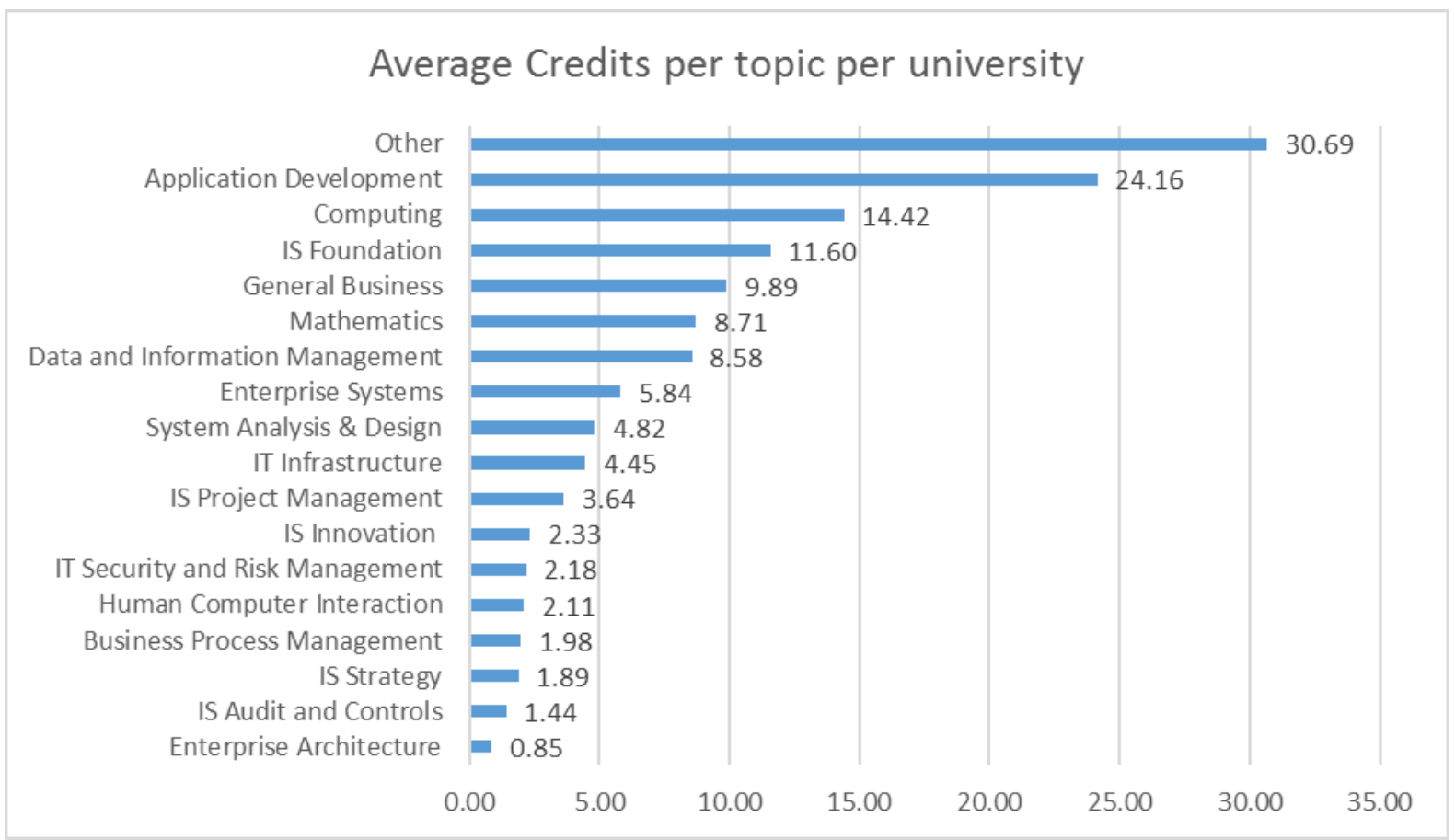

Fig 1. Average Credits per topic in IS Undergraduate Programs in Indonesia (per March 28, 2017)

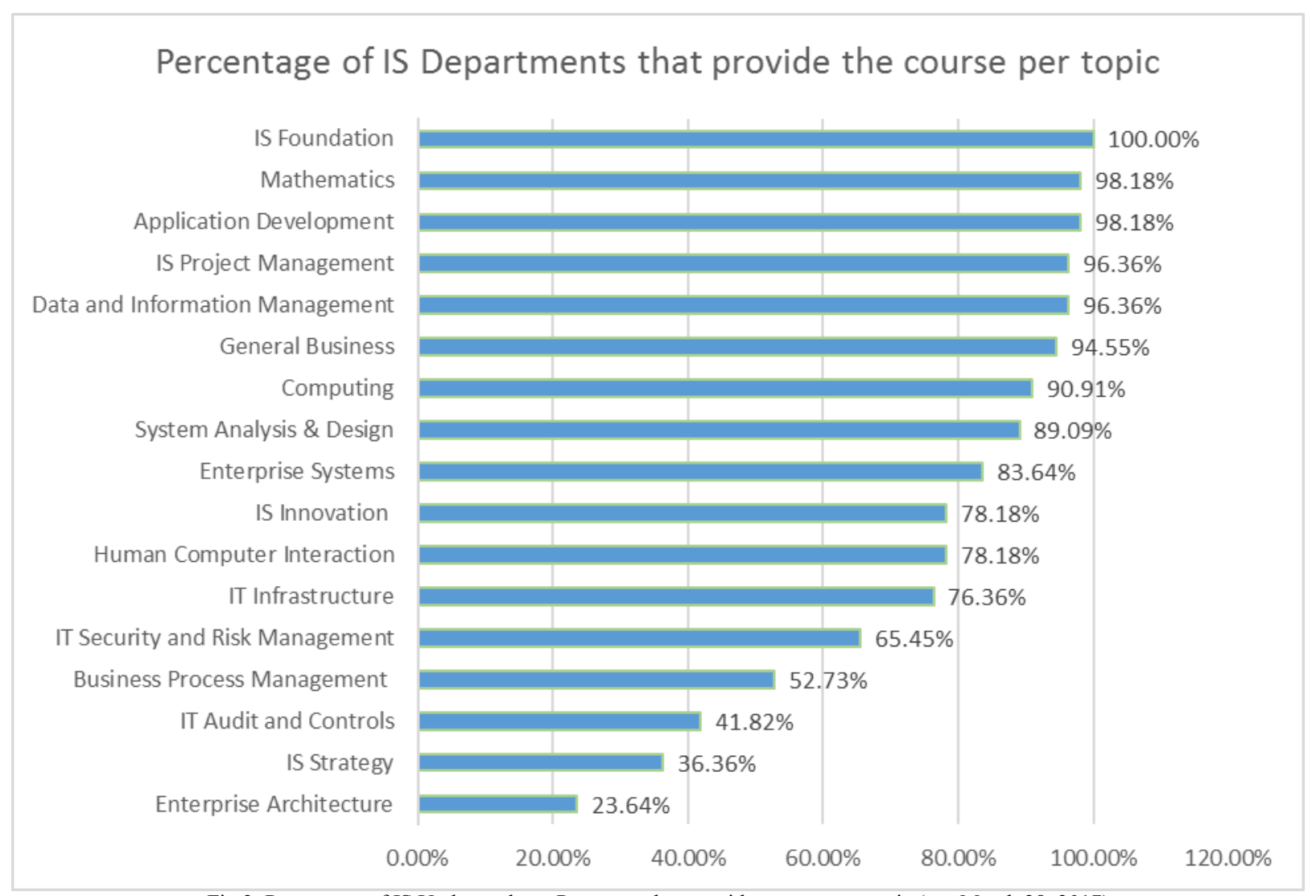

Fig 2. Percentage of IS Undergraduate Programs that provide courses per topic (per March 28, 2017)

In addition, the IS Undergraduate programs also demonstrate less support to IT Management and Planning. Subjects that are corresponding to this topic are not widely accessible (see Fig 2). To name a few, Enterprise
Architecture is only available in $24.64 \%$ IS undergraduate programs while IT audit \& controls is only $41 \%$ and IS Strategy is only $36,36 \%$. Nevertheless, the topic of IT backbones uses such as IT Infrastructure and IT Security and 
Risk Management are fairly taught (see Fig 2). As a mediocre priority, the existence of IT backbone topics may partially contribute to IT Management and Planning as low-level operational skill and knowledge.

\section{CONCLUSION AND FURTHER RESEARCH}

This paper discusses the application of one of the notable IS curriculum guidelines named ACM/AIS IS 2010 in the IS undergraduate programs in Indonesia. We manually gather data from 55 IS undergraduate programs in which syllabuses are available in the official website.

We have found that IS undergraduate programs in Indonesia do not completely adhere what ACM/AIS IS 2010 has given. Enterprise Architecture is the least given topics in all universities, even though ACM/AIS IS 2010 has determined its importance. Besides, we have also found that there is a substantial growth of IS Strategy, Management \& Acquisition topic adoption especially in public universities. Unfortunately, this growth does not apply to private universities in which average credits are still non substantial.

Also, there is no significant different of local direction with our similar study in 2013 [12]. The de-facto local direction of IS undergraduate programs in Indonesia is stable at System Development; even though ACM/AIS IS 2010 has taken away Application Development from the IS cores. We suggest that this situation is more industrial driven rather than academic driven. In the long period of time, this System Development focus may reduce the IS graduate employability. This happens because similar disciplines such as computer science or information technology have also equipped their graduate with substantial amount of credits in System Development. Hence it may confuse employer to find a suitable graduate to fulfill his/her business requirements.

Further research may pertain several questions such as 1) Is it true that some under taught parts of Enterprise Architecture and IS Strategy are given in IS postgraduate level 2) Can we cluster IS Undergraduate programs into several groups according to credit per topic basis, if it can then what clusters are they? 3) In terms of application development, what are the content differences between courses that of IS programs and that of other computing programs. 


\section{REFERENCES}

[1] D. Cecez-Kecmanovic, "The discipline of information systems: issues and challenges," in AMCIS 2002 Proceedings, 2002

[2] S. Larson and M. C. R. Harrington, "A Survey of ABET Accredited Information Systems Undergraduate Programs in the USA," in 2012 Proceedings of the Information Systems Educators Conference, 2012.

[3] M. Sagheb-Tehrani, "Towards a consistency of information systems curriculum,” Issues Inf. Syst., vol. 16, pp. 28-37, 2015.

[4] H. Adelsberger et al., "An interpretive evaluation of interviews with renowned researchers: Part II - Results Information Systems Discipline," 2005.

[5] H. Topi et al., "IS 2010 Curriculum Guidelines for Undergraduate Degree Programs in Information Systems Association for Computing Machinery (ACM) Association for Information Systems (AIS),” 2010.

[6] The Joint Task Force for Computing Curricula 2005, "Computing Curricula 2005," 2005.

[7] J. Cougar, "J.D Cougar, 'Curriculum Recommendations for Undergraduate Programs in Information Systems,' Communications of the ACM," Commun. ACM, 1973.

[8] ACM Committee on Computer Curricula of ACM Board ACM, "ACM curricula recommendations for information systems, Volume II," 1983.

[9] H. E. Longenecker and D. L. Feinstein, "A Comprehensive Survey of USA and Canadian Undergraduate Programs in Information Systems," $J$. Inf. Syst. Educ., vol. 3, pp. 8-13, 1991.

[10] G. B. Davis, J. T. Gorgone, J. D. Couger, D. L. Feinstein, and H. E. Longenecker, "IS '97 Model Curriculum and Guidelines for Undergraduate Degree Programs in Information Systems," ACM SIGMIS Database, vol. 28, no. 1, 1996.

[11]J. T. Gorgone, G. B. Davis, J. S. Valacich, D. L. Feinstein, and H. E. Longenecker, "IS 2002 Model Curriculum and Guidelines for Undergraduate Degree Programs Information Systems,” 2002.

[12]A. Wibisono and A. S. Nisafani, "Curriculum Structure of the Undergraduate Programs of Information Systems in Indonesia in the Year of 2013," in Information Systems International Conference, 2013, pp. 207-2012.

[13]N. Herbert, K. De Salas, I. Lewis, J. Dermoudy, and L. Ellis, "ICT Curriculum and Course Structure: the Great Balancing Act," in Proceedings of the Sixteenth Australasian Computing Education Conference, 2014, pp. 21-30.

[14]H. Drew, Z. Ma, and W. Ming, "The Information Systems Core: A Study from the Perspective of IS Core Curricula in the U.S.," Inf. Syst. Educ. J., vol. 13, 2015.

[15]M. Fotache, G. Olaru, and V. Iacoban, "Information Systems Analysts and Designers. Academic/Research Supply vs Market Demand," in Procedia Economics and Finance, 2015, vol. 20, pp. 232-242. 